Avello-Fernández, L., Izaguirre, E., Vidal, M., Martínez, A., \& Hernández, L. (2018). Remote supervision and control based on wireless technology to operation of central pivot irrigation machine. Sistemas \& Telemática, 16(44), 63-74.

\title{
Remote Supervision and Control Based on Wireless Technology to Operation of Central Pivot Irrigation Machine
}

\author{
Lianet Avello Fernández (1) / lavello@uclv.cu \\ Eduardo Izaguirre Castellanos (1) / izaguirre@uclv.edu.cu \\ Manuel Luciano Vidal Díaz (2)/ I.vidal@inica.azcuba.cu \\ Alain S. Martínez Laguardia (1)/ amguardia@uclv.edu.cu \\ Luis Hernández Santana (1)/ luishs@uclv.edu.cu \\ Universidad Central "Marta Abreu" de Las Villas, Cuba ${ }^{(1)}$ \\ Instituto de Investigaciones de la Caña de Azúcar (INICA), Cuba ${ }^{(2)}$
}

\begin{abstract}
The availability of water resources in agriculture is a growing concern throughout the planet. The new technologies of automation and communications offer a set of solutions for the collection and analysis of information that make possible the decision making in the modern systems of agricultural irrigation. Important steps have been taken in the automation of irrigation systems, focused on the adequate determination of water requirements in crops, which has a positive effect on the saving of energy carriers, water resources, and agricultural productivity. In the present research we propose to perform a real-time control and monitoring system, allowing the operation and remote monitoring of irrigation machines of center pivot. For this, a programmable logic controller and wireless communication technology are used, according with the requirements and characteristics of the context of agricultural application.
\end{abstract}

KEYWORDS Remote monitoring; center pivot irrigation machine; programmable logic controller; wireless technology.

Supervisión remota y control basado en tecnología inalámbrica para la operación de máquina de riego de pivote central

RESUMEN La disponibilidad de recursos hídricos para la agricultura es una preocupación creciente en el planeta. Las nuevas tecnologías de la automatización y las comunicaciones ofrecen un conjunto de soluciones para la recolección y el análisis de información que posibilita la toma de decisiones en los sistemas modernos de irrigación agrícola. Se han dado importantes pasos en la automatización de los sistemas de riego, enfocados en determinar los requerimientos adecuados de agua en los cultivos, lo cual incide positivamente en el ahorro de portadores energéticos y recursos hídricos, y en el aumento de la productividad. En el presente trabajo se propone un sistema de control y supervisión en tiempo real, que permite la operación y el monitoreo remoto de máquinas de riego de pivote central. Para ello se emplea un autómata programable y tecnología de comunicación inalámbrica, de acuerdo con las exigencias y características asociadas al contexto de aplicación agrícola.

PALABRASCLAVE Supervisión remota; máquina de riego de pivote central; autómata programable; tecnología inalámbrica.
Monitoramento remoto e controle baseados em tecnologia sem fio para a operação da máquina de irrigação de pivô central

RESUMO A disponibilidade de recursos hídricos para a agricultura é uma preocupação crescente do planeta. As novas tecnologias de automação e as comunicações oferecem um conjunto de soluções para a coleta e análise de informação que permite a tomada de decisões em sistemas de irrigação agrícola modernos. Têm sido dados passos importantes na automação de sistemas de irrigação, focados na determinação das necessidades adequadas de água nas culturas, o que afeta positivamente a poupança de fontes de energia e recursos hídricos, bem como o aumento da produtividade. No presente trabalho, é proposto um sistema de controle e supervisão em tempo real, o que permite a operação e o monitoramento remoto de máquinas de irrigação de pivô central. Para isso, são utilizados um autômato programável e tecnologia de comunicação sem fio, de acordo com os requisitos e características associadas ao contexto de aplicação agrícola.

PALAVRAS-CHAVE Supervisão remota; máquina de irrigação de pivô central; Autômato programável; tecnologia sem fio. 


\section{Introduction}

Agriculture is a decisive and strategic sector for the $\mathrm{Cu}$ ban economy. The rational and efficient use of water and energy carriers in this branch is one of the most important items in the country's politics. Generally, in this sector, high consumption is generated due to excessive irrigation. Therefore, the correct operation of these systems allows a quality production and the saving of considerable volumes of this important natural resource (Jimenez, 2011).

Cuba has experienced increasingly prolonged periods of drought in recent years. There is a tendency of extensive droughts, as a result of climate change (González, 2016; Vázquez \& Solano, 2013). Currently, although irrigation systems are implemented in several types of crops, exceptional attention is required to the cultivation of sugarcane, due to the high volumes of water it uses. Agricultural irrigation systems, which are generally used, are manually controlled, which causes, in many cases, the waste of water and electricity (Carranza, 2016).

Despite the efforts made, the control of irrigation systems in Cuba is not automated. Irrigation programming in many places remains empirical, and there are low irrigation efficiency rates reported. Hence, it is intended to increase the surfaces under irrigation, including the assembly of new electric center pivot machines, which are characterized by their high efficiency (Clavelo, \& Seguí, 2012). Therefore, important investment programs have been developed for the manufacture and acquisition of modern equipment that integrates the new technologies of automation, control, and communications, with the aim of developing a sustainable and productive agriculture (Jimenez, 2011).

In this context, the current study aims to propose a control solution through a programmable automaton and remote supervision using wireless technology for the automated operation of center pivot irrigation machines.

As a contribution of the current research, thanks to the remote supervision of the operation of this type of irrigation machine, it is possible to control it remotely, as well as carry out operations to control its execution, such as the programming of the irrigation time, the direction of rotation, and the hours of work. It responds to the challenge imposed by the context of an agricultural application, proposing a communication solution based on wireless transmission. The architecture of the system and the control proposal have the necessary flexibility that the system can be applied in correspondence

\section{Introducción}

La agricultura es un sector decisivo y estratégico para la economía cubana, por lo que el uso racional y eficiente del agua y de los portadores energéticos en esta rama constituye uno de los renglones de mayor prioridad en la política del país.Generalmente, en este sector los altos consumos se generan debido al exceso de riego. Por consiguiente, el correcto funcionamiento de estos sistemas permite la producción con calidad y el ahorro de considerables volúmenes de este importante recurso natural (Jimenez, 2011).

Cuba ha experimentado períodos cada vez más prolongados de sequía en los últimos años y existe la tendencia a que ellos sean más extensos, como producto de los cambios climáticos (González, 2016; Vázquez \& Solano, 2013). Actualmente, aunque se implementan sistemas de irrigación en varios tipos de cultivos, se le presta una excepcional atención al cultivo de la caña de azúcar, por los altos volúmenes de agua que utiliza. Los sistemas de riego agrícola, que generalmente se utilizan, son de control manual, lo que provoca, en muchos casos, el desperdicio de agua y de energía eléctrica (Carranza, 2016).

No obstante, a pesar de los esfuerzos realizados, el control de los sistemas de riego en Cuba no está automatizado, la programación del riego en muchos lugares continúa siendo empírica, y se reportan bajos porcientos de eficiencia del riego. En este sentido, se pretende incrementar las superficies bajo riego, incluyendo el montaje de nuevas máquinas de pivote central eléctricas, las cuales se caracterizan por su alta eficiencia (Clavelo \& Seguí, 2012). Debido a ello, se han desarrollado importantes programas de inversiones para la fabricación y adquisición de equipamientos modernos que integran las nuevas tecnologías de automatización, control y comunicaciones, con el objetivo de desarrollar una agricultura sostenible y productiva (Jimenez, 2011).

En este contexto, el presente trabajo tiene como objetivo proponer una solución de control mediante un autómata programable y supervisión remota utilizando tecnología inalámbrica para la operación automatizada de máquinas de riego de pivote central.

Como aporte de la investigación tenemos que, gracias a la supervisión remota de la operación de este tipo de máquina de riego, es posible gobernar a distancia la misma, así como efectuar las operaciones de control de su funcionamiento, entre ellas la programación del tiempo de riego, el sentido de giro y las horas de trabajo. Se responde al desafío que impone el contexto de aplicación agrícola, proponiendo una solución de comunicación basada en transmisión inalámbrica. La arquitectura del sistema y la propuesta de control poseen la flexibilidad necesaria para que el sistema pueda ser aplicado en correspondencia con las posibilidades de comunicación específicas del lugar donde se decida su implementación, así como de las necesidades del usuario. A su vez, la supervisión remota del funcionamiento de la máquina de riego permite a los directivos conocer, en tiempo real, el estado de su operación, las alarmas, los reportes y los históricos de los regímenes de riego, lo que representa la disponibilidad de la información de las variables 
necesarias para la toma de decisiones. Se puede también generalizar su empleo a un conjunto de máquinas de riego. Todo ello impacta desde las perspectivas económica, social y medio ambiental, al aprovechar más eficientemente los recursos hídricos, hacer un mejor uso de los portadores energéticos, mejorar los niveles productivos y reducir los costos de la producción agrícola.

La investigación aplica el método hipotético-deductivo, al elaborar la hipótesis de investigación a partir de los resultados derivados de la revisión bibliográfica, la preparación del marco teórico y el planteamiento de la problemática; el método sistémico, al relacionar varias problemáticas para obtener una más amplia y consecuentemente plantear las correspondientes soluciones; y el método experimental, al efectuar las pruebas experimentales para comprobar y evaluar el desempeño del sistema en su conjunto.

\section{Desarrollo}

El riego se puede definir como la ciencia de la aplicación artificial de agua a la tierra o el suelo (USDA, 1991; Pasha \& Yogesha, 2014), su objetivo fundamental es suplir la humedad necesaria al cultivo, se puede realizar para ayudar al crecimiento de las plantaciones agrícolas o para el mantenimiento de los paisajes o de la vegetación del suelo en zonas secas y durante los períodos de escasez de lluvia. El riego tiene algunos otros usos en la producción de cultivos, que incluyen: la protección de las plantas contra las heladas, la supresión de las malas hierbas y la prevención de la consolidación del suelo (Kumar, Pramod, \& Sravani, 2013). Sin importar el método de riego usado, el propósito de la irrigaciones es reponer periódicamente el almacenamiento de la humedad del suelo en la zona radicular de la planta (Camargo, 2013).

Los métodos y técnicas de riego son los encargados de conducir y aplicar el agua para la irrigación, desde la fuente de abasto y la red de conducción, y lograr el estado de humedad necesario del suelo. Por consiguiente, es fundamental que estos satisfagan el régimen de riego definido para los cultivos que beneficien, garanticen una adecuada productividad del trabajo y propicien la mecanización y automatización del proceso de riego (Kumar et al., 2013).

Básicamente, son tres los métodos de riego utilizados: riego por superficie, riego por aspersión y riego localizado (Santos, De Juan, Picornell, \& Tarjuelo, 2010). Este trabajo se centra específicamente en el riego por aspersión mediante máquinas de riego de pivote central, las que se caracterizan por su alta eficiencia.

\section{A. Máquinas de riego de pivote central}

Las máquinas de riego de riego de pivote central (FIGURA 1) utilizan tecnologías de irrigación por aspersión y garantizan una eficiencia del riego del 80 \% (Rodríguez \& López, 2014; Rodríguez \& Puig, 2012). Se componen de una torre central y un variado número de tramos estructurales con sus correspondientes torres móviles. La máquina riega en forma circular, en el proceso, las boquillas difusoras se seleccionan apropiadamente para cada tramo en cuestión (Tarjuelo, 2005). Como el with the specific communication possibilities of the place where its implementation is decided, as well as the user needs. At the same time, the remote supervision of the irrigation machine operation allows managers to know, in real time, the status of their functioning, alarms, reports, and historical irrigation schemes, which represents the information availability of the variables necessary for decision making. It can also be generalized to a set of irrigation machines. All the above impacts from the economic, social and environmental perspectives, by making more efficient use of water resources, making better use of energy carriers, improving production levels and reducing the costs of agricultural production.

The research applies the hypothetical-deductive method, when developing the research hypothesis based on the results derived from the bibliographic review, the theoretical framework preparation, and the problem approach. It also uses the systemic method, by relating several problems to obtain a broader issue and consequently propose the respective solutions; and the experimental method, when performing the experimental tests to check and evaluate the performance of the system as a whole.

\section{Development}

Irrigation can be defined as the science of the artificial application of water to land or soil (USDA, 1991; Pasha \& Yogesha, 2014), its main objective is to supply the necessary moisture to the crop. It can be done to help growth of agricultural plantations or for the maintenance of landscapes or soil vegetation in dry areas and during periods of low rainfall. Irrigation has some other uses in crop production, which include: protecting plants against frost, suppressing weeds, and preventing soil consolidation (Kumar, Pramod, \& Sravani, 2013). Regardless the irrigation method used, the purpose of irrigation is to periodically replenish the storage of soil moisture in the root zone of the plant (Camargo, 2013).

Irrigation methods and techniques are responsible for driving and applying water for irrigation, from the supply source and the conduction network, in order to achieve the necessary soil moisture status. Therefore, it is essential that they meet the irrigation regime defined for crops that benefit, guarantee adequate labor productivity and encourage the mechanization and automation of the irrigation process (Kumar et al., 2013).

Basically, there are three irrigation methods used: surface irrigation, sprinkler irrigation and localized irriga- 
tion (Santos, De Juan, Picornell, \& Tarjuelo, 2010). This study focuses specifically on sprinkler irrigation using center pivot irrigation machines, which are characterized by their high efficiency.

\section{A. Center Pivot Irrigation Machines}

The center pivot irrigation machines (FIGURE 1) use sprinkler irrigation technologies and guarantee irrigation efficiency of 80\% (Rodríguez \& López, 2014; Rodríguez $\&$ Puig, 2012). They consist of a tower center and a varied number of structural sections with their corresponding mobile towers. The machine irrigates in a circular way, in the process, the diffuser nozzles are selected appropriately for each section in question (Tarjuelo, 2005). As the flow rate of the pivot is constant, the water applied per unit area is smaller at higher rotational speed of the machine. Therefore, the amount of water to be applied is controlled according to the speed of the machine (Pérez, 2010).

Its advantages include: it is possible to apply frequent (daily) irrigations, which contributes to a better water and nutrients management. It allows fertilizers to be applied, in a process known as ferti-irrigation, which reduces the use of other external machineries. It is a system that works at low pressure; therefore, the energy expenditure is lower; and it is possible to modify rainfall, which allows the system to adapt to different types of soil and crops.

However, these machines also have some disadvantages such as: the high initial cost; the demand of qualified operators to obtain an efficient use of water. On the other hand, since it is a circular irrigation system, the land must be prepared in an appropriate way or irrigation surface can be lost in the corners (Pérez, 2010).

Currently, the standard irrigation machines have an elementary level of automation, very typical of their work functions, to be controlled by an operator; they have a control panel, from where their fundamental functions are governed, including starting and stopping the machine, selecting the operating mode (manual-automatic), and selecting the direction of rotation and speed of rotation (FIGURE 2). In automatic mode, the condition of not allowing the machine to work is conceived if the pumping station is not supplying water, which prevents it from turning dry. It also establishes that, in the case that the machine stops rotating, the pumping of water must be stopped, thus guaranteeing not to irrigate on the same point. The operating time is controlled by the percentage relay, which conforms the desired irrigation standard. There are other



caudal del pivote es constante, a mayor velocidad de giro de la máquina, el agua aplicada por unidad de superficie es menor. Por consiguiente, la cantidad de agua a aplicar se controla en función de la velocidad de la máquina (Pérez, 2010).

Sus ventajas son: es posible aplicar riegos frecuentes (diarios), lo que contribuye a un mejor manejo del agua y nutrientes; permite aplicar fertilizantes, en proceso conocido como ferti-irrigación, lo que disminuye el uso de otras maquinarias externas; es un sistema que trabaja a baja presión, por lo cual el gasto en energía es menor; y es posible modificar la pluviometría, lo que le permite al sistema adaptarse a distintos tipos de suelo y cultivo.

Sin embargo, estas máquinas también poseen algunas desventajas como son: el alto costo inicial; la demanda de operadores calificados para obtener un uso eficiente del agua. Por otro lado, al ser un sistema de riego circular, debe prepararse el terreno de forma adecuada o puede perderse superficie de riego en las esquinas (Pérez, 2010).

Actualmente, las propias máquinas de riego estándar poseen un elemental nivel de automatización, muy propio de sus funciones de trabajo, para ser controladas por un operador; poseen un panel de control, desde donde se gobiernan sus funciones fundamentales, entre ellas el arranque y la parada de la máquina, la selección del modo de funcionamiento (manual-automático), y la selección del sentido de rotación y velocidad de giro (FIgura 2). En el modo automático, se concibe la condición de no permitir que la máquina trabaje si la estación de bombeo no está suministrando agua, lo que le evita girar en seco. También establece que, en caso de que la máquina deje de rotar, debe pararse el bombeo de agua, garantizando así no regar sobre un mismo punto. El tiempo de funcionamiento se controla mediante el denominado relé porcentual, que se ajusta a la norma de riego deseada. Existen otros automatismos básicos como son: el ajuste del presostato para un rango de presión determinada y la medición del voltaje y protección de los límites de voltajes de alimentación permisibles (Tarjuelo, 2005; Pérez, 2010). 


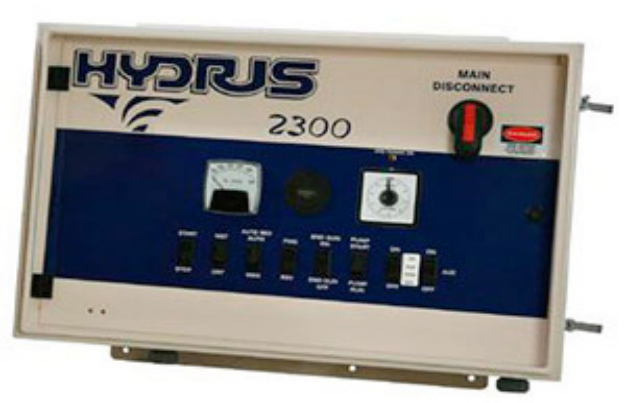

Figure 2. Central pivot irrigation machine: Example of control panel / Máquina de riego de pivote central: ejemplo de panel de control

Las técnicas modernas de riego utilizando pivotes posibilitan incluir herramientas para la recolección, el análisis y la transmisión de datos en tiempo real, con el objetivo de facilitar la toma de decisiones para desarrollar una agricultura de precisión (Capraro, Tosetti, \& Vita-Serman, 2014; Kranz, Evans, Lamm, O'Shaughnessy, \& Peters, 2010). En este contexto, se destacan las máquinas de pivote central, que cuentan con un alto grado de automatización, generado por los avances tecnológicos alcanzados en los últimos tiempos en el sector agrícola.

Existen en el mundo varias empresas productoras de este tipo de tecnología. Sus productos incluyen sistemas que controlan el funcionamiento total del equipo desde un panel central o a través de acceso remoto. Estas empresas han desarrollado sensores electrónicos, controladores y protocolos de comunicación para satisfacer las exigencias de riego. Tal es el caso de las firmas "IRRIMEC", "Cuñat Agrocaja" y "Valley Irrigation" (Reductores CUÑAT S.A., 2017; Reinke Irrigation, 2017; Valley Irrigation, 2017). No obstante, el costo de estas tecnologías es alto. En Cuba se han importado varias de estas máquinas, muchas de ellas destinadas al cultivo de la caña de azúcar; además, se producen a nivel nacional, con el objetivo de disminuir las importaciones y reducir los costos de inversión. Por consiguiente, la problemática de implementar la operación y monitoreo remoto en las máquinas de pivote constituye una estrategia a seguir en el sector agrícola, con el fin de obtener ventajas importantes desde los puntos de vista económico, medioambiental y energético.

\section{B. Tecnología inalámbrica en sistemas de riego}

Específicamente en las máquinas de riego de pivote central, la selección de la tecnología de comunicación para su operación remota y control constituye un aspecto importante a considerar, dado que garantiza una mejor explotación y supervisión de la máquina.

En el contexto agrícola, las comunicaciones inalámbricas desempeñan un papel cada vez más importante, ya que permiten servicios de transmisión de información a largas distancias, imposibles de implementar utilizando cables (Kranz et al., 2010; Smith, Baillie, McCarthy, Raine, \& Baillie, 2011 ). En ello influyen la topografía local y regional y el costo de la tecnología a emplear, de manera que se garantice la fiabilidad del sistema de supervisión (Pfitscher et al., 2011).

Entre las diferentes vías de transmisión inalámbrica que se aplican en la agricultura se encuentran las redes de sensores basic automations such as: adjusting the pressure switch for a specific pressure range and measuring the voltage, as well as protecting the limits of permissible supply voltages (Tarjuelo, 2005; Pérez, 2010).

Modern irrigation techniques using pivots make it possible to include tools for the collection, analysis, and transmission of data in real time, with the aim of facilitating decision-making to develop precision agriculture (Capraro, Tosetti, \& Vita-Serman, 2014; Kranz, Evans, Lamm, O'Shaughnessy, \& Peters, 2010). In this context, the center pivot machines stand out, which have a high degree of automation, generated by the technological advances reached recently in the agricultural sector.

There are several companies in the world that produce this type of technology. Its products include systems that control the total operation of the equipment from a panel center or through remote access. These companies have developed electronic sensors, controllers, and communication protocols to meet irrigation requirements. Such is the case of the firms "IRRIMEC", "Cuñat Agrocaja" and "Valley Irrigation" (Reductores CUÑA S.A., 2017; Reinke Irrigation, 2017; Valley Irrigation, 2017). However, these technologies have a high cost. In Cuba, several of these machines have been imported, many of them destined for the sugarcane cultivation. In addition, they occur at the national level, with the aim of reducing imports and investment costs. Therefore, the issue of implementing the operation and remote monitoring in the pivot machines constitutes a strategy to follow in the agricultural sector, in order to obtain important advantages from the economic, environmental, and energy points of view.

\section{B. Wiireless Technology in Irrigation Systems}

Specifically, in center pivot irrigation machines, the selection of communication technology for remote operation and control is an important aspect to consider, since it guarantees better exploitation and machine supervision.

In the agricultural context, wireless communications play an increasingly important role, since they allow information transmission services over long distances, which are impossible to implement using cables (Kranz et al., 2010; Smith, Baillie, McCarthy, Raine, \& Baillie, 2011). This is influenced by local and regional topography as well as the cost of the technology to be used, with the aim to guarantee the reliability of the supervision system (Pfitscher et al., 2011). 
The sensor networks based on radiofrequency communication (RF, VHF, UHF) are among the different wireless transmission routes that are applied in agriculture. The VHF bands [Very High Frequency] and UHF [Ultra High Frequency] constitute a technology that offers higher data transmission speeds than most conventional radio modems, and also provides greater flexibility in terms of monitoring and control of radio frequency irrigation systems, which are located at great distances from the control points. Other methods of wireless transmission are: WiFi networks, Bluetooth, and GSM mobile networks [Global System for Mobile Communications] and GPRS [General Packet Radio Service]. These types of mobile telecommunications enable the transfer of large volumes of data at high speeds. Communication systems based on mobile telephony allow the operator to consult the main control panel or the base computer from any location and at any time (Chávez, Pierce, Elliott, \& Evans, 2010; Dong, Vuran, \& Irmak, 2013; Pavithra \& Srinath, 2014).

\section{Supervision and Control of Irrigation Systems}

In recent years, the use of SCADA control and supervision systems (Supervisory Control and Data Acquisition) has increased in process automation (Gurban \& Andreescu, 2011), in almost all types of industries where the monitoring and control of the variables associated to the process is required; mainly, when the decision making can be carried out remotely and in real time.

Regarding agricultural irrigation systems, the use of SCADA systems represents a global trend, due to its implementation, it is possible to control and supervise the irrigation system at a distance. In this way, the farmer can have full access to the process by viewing it on a computer screen, telephone or tablet. Therefore, he can obtain the information of the process and the state of the crop variables in real time. It also allows to store information in historical records, handle alarms and events, generate periodic reports and manage databases for information processing and decision making (Navarro, Martinez, Domingo, Soto, \& Torres, 2016).

Another of its utilities is that the supervisor system can easily be integrated with other systems based on interactive platforms and web pages, through access to the history of the alarms in such a way that, if any system failure occurs, either electrical or communication, the supervisor can quickly stop the process and avoid major problems (Alghazali, Alkhaddar, \& Hadi, 2013). basados en comunicación mediante radiofrecuencia (RF, VHF,UHF). Las bandas VHF [ Very High Frequency] y UHF [Ultra High Frequency] constituyen una tecnología que ofrece velocidades de transmisión de datos más altas que la mayoría de los radio módems convencionales, además brinda mayor flexibilidad en cuanto al monitoreo y control de los sistemas de riego ubicados a grandes distancias de los puntos de control. Otros métodos de transmisión inalámbrica son: las redes WiFi, el Bluetooth y las redes de telefonía móvil GSM [Global System for Mobile Communications] y GPRS [General Packet Radio Service]. Estos tipos de telecomunicaciones móviles posibilitan la transferencia de grandes volúmenes de datos a altas velocidades. Los sistemas de comunicación basados en telefonía móvil permiten al operador consultar el panel de control principal o la computadora base desde cualquier ubicación y en cualquier momento (Chávez, Pierce, Elliott, \& Evans, 2010; Dong, Vuran, \& Irmak, 2013; Pavithra \& Srinath, 2014).

C. Supervisión y control de sistemas de riego

En los últimos años se ha incrementado el uso de sistemas de control y supervisión SCADA (Supervisory Control And Data Acquisition) en la automatización de procesos (Gurban \& Andreescu, 2011) en casi todo tipo de industrias donde se requiera de un monitoreo y control de las variables asociadas al proceso, principalmente si la toma de decisiones se puede realizar a distancia y en tiempo real.

En lo que concierne a los sistemas de irrigación agrícola, el uso de sistemas SCADA representa una tendencia mundial, ya que gracias a su implementación se logra controlar y supervisar el sistema de riego a distancia. De esta forma, el agricultor puede tener acceso completo al proceso mediante su visualización en una pantalla de computadora, teléfono o tableta, y disponer así, en tiempo real, de la información del proceso y del estado de las variables del cultivo. Además, le posibilita almacenar la información en registros históricos, tratar las alarmas y eventos, generar reportes periódicos y manejar bases de datos para el procesamiento de la información y la toma de decisiones (Navarro, Martinez, Domingo, Soto, \& Torres, 2016).

Otra de sus utilidades es que el sistema supervisor puede fácilmente ser integrado con otros sistemas basados en plataformas interactivas y páginas web, brindando así acceso al historial de las alarmas de forma tal que, si ocurre alguna falla en el sistema, ya sea eléctrica o de comunicación, el supervisor pueda detener rápidamente el proceso y evitar mayores problemas (Alghazali, Alkhaddar, \& Hadi, 2013).

De manera general, las acciones de control y adquisición de datos del sistema de riego se pueden realizar a través de autómatas programables u otros dispositivos de control asociados al SCADA (Joshi, Bhujbal, \& Kurkute, 2016).

En la literatura se reportan numerosas publicaciones donde se utilizan los autómatas programables para el control del riego. Esta tecnología se caracteriza por su alta fiabilidad y robustez, y por proporcionar facilidades para la comunicación industrial, sea cableada o inalámbrica (Maheshwari \& Sindha, 2014).

Entre los fabricantes de estos dispositivos, se encuentra la firma Schneider Electric, la cual produce y comercializa toda 
una gama de autómatas para disímiles aplicaciones de control. El autómata TM241CE40R de la firma Schneider Electric, se encuentra entre los dispositivos de hardware que poseen las características y funcionalidades en su diseño para controlar las máquinas de riego de pivote central (Schneider Electric, 2017). Por consiguiente, se toma la decisión del empleo de este dispositivo en una configuración adecuada de E/S para implementar la solución propuesta (Avello, Izaguirre, Martínez, \& Hernández, 2017).

\section{Resultados y discusión}

Teniendo en cuenta la disponibilidad de un puerto Ethernet integrado, que ofrece servicios de FTP y un Servidor Web, en el autómata TM241CE40R, se propone el diseño (empleando el propio software de programación del dispositivo) de una visualización web en formato HTML5, que garantice la supervisión y operación remota de la máquina de riego en tiempo real. Este tipo de formato de páginas web permite la fácil integración de sistemas de control con la supervisión remota de maquinarias, mediante aplicaciones para teléfonos inteligentes, tabletas y computadoras, característica que lo hace ideal para su utilización en el contexto de aplicaciones agrícolas.

\section{A. Soluciones de control y supervisión}

En este sentido, se propone como primer paso implementar la solución para el control y supervisión remota cuya arquitectura general se muestra en la Figura 3. Dadas las dificultades de comunicación mediante sistemas cableados en el contexto de aplicaciones agrícolas, se propone una solución de transmisión inalámbrica económicamente factible, aprovechando las posibilidades que brinda el autómata programable seleccionado de operar como servidor Web, y la disponibilidad de los recursos de hardware y software que son empleados.

El autómata programable estará ubicado como estación local, físicamente cercano al panel de control de la máquina de riego; él mismo se programa para controlar las funciones de
Generally, stock control and data acquisition irrigation system can be performed by programmable logic controllers or other control devices associated with the SCADA (Joshi, Bhujbal, \& Kurkute, 2016).

In the literature, numerous publications are reported where programmable automatons are used for irrigation control. This technology is characterized by its high reliability and robustness, and accessibility to wired or wireless industrial communication (Maheshwari \& Sindha, 2014).

The Schneider Electric company is one of these devices manufacturers, which produces and markets a whole range of automata for different control applications. The TM241CE40R automaton firm Schneider Electric is one of the hardware devices that have the features and functionality in its design to control center pivot irrigation machines (Schneider Electric, 2017). Therefore, this device is used in a suitable configuration of I / O to implement the proposed solution (Avello, Izaguirre, Martínez, \& Hernández, 2017).

\section{Results and Discussion}

Taking into account the availability of an integrated Ethernet port, which offers FTP services and a Web Server, in the TM241CE40R PLC, we propose the design (using the own device programming software) of a web display in HTML5 format, which guarantees the supervision and remote operation of the irrigation machine in real time. This type of web page format allows the easy integration of control systems with the machines remote supervision. The above through applications

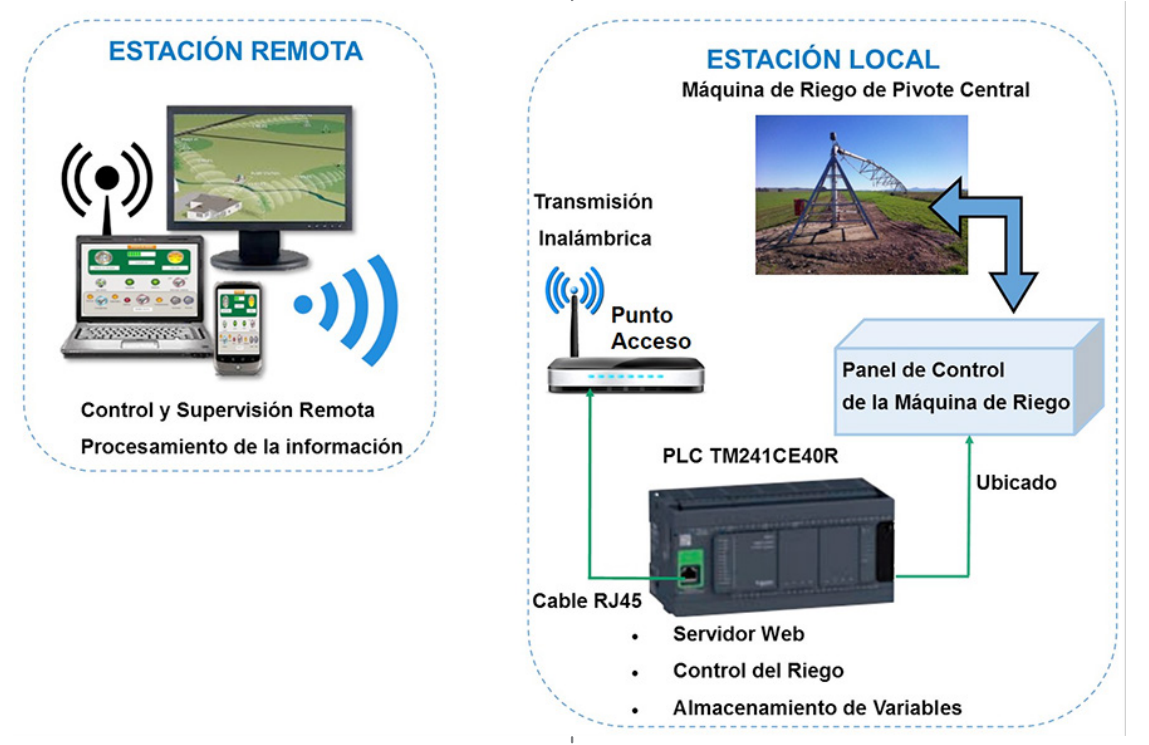

Figure 3. Proposal of remote control and supervision applied to a central pivot irrigation machine / Propuesta de control y supervisión remota àplicada a máquinas de riego de pivote central 
for smartphones, tablets and computers, an important feature in the context of agricultural applications.

\section{A. Control and Supervision Solution}

As a first step, it is proposed to implement the solution for remote control and supervision whose general architecture is shown in Figure 3. Given the difficulties of communication through wired systems in the context of agricultural applications, a wireless transmission solution is proposed economically feasible, taking advantage of the possibilities offered by the programmable automaton selected to operate as a Web server, and the availability of hardware and software resources that are used.

The programmable automaton will be located as a local station, physically close to the control panel of the irrigation machine. It is also programmed to control the irrigation functions. The inputs and outputs are properly configured and connected to the control and drive devices, arranged in the control panel of the machine, which does not undergo substantial modifications with respect to its original design.

In the internal memory of the automaton can be stored the historical results of important variables related to irrigation, such as, for example: irrigation hours, machine speed, irrigation frequency, number of turns made by the machine, or others variables decided by the client.

A WiFi wireless access point connected to the PLC's Ethernet port will be used for the data transmission, using TCP / IP communication protocol. Subsequently, the control and supervision of irrigation parameters can be done from a remote station, using smart mobile devices, tablets or laptops, looking for flexibility, according to the possibilities and client needs. It can also operate from the local station itself, where it will have access to the PLC and its hardware configuration. Then, the information handled by itself, may be displayed on a web page that can be re-designed for each specific machine or for a set of them, providing the ability to process the irrigation data for decision making. The above, according to the characteristics and the application context (crop type, water resources availability, maintenance needs, etc.).

\section{B. Web Visualization}

Depending on the proposed solution, the graphical user interface shown in Figure 4 is designed. The programming of its visual elements and dynamic links with the system variables is done using the SoMachine v4.1 SP2 software. riego; las entradas y salidas son debidamente configuradas y conectadas a los dispositivos de mando y accionamiento, dispuestos en el panel de control de la propia máquina, el cual no sufre modificaciones sustanciales respecto de su diseño original.

En la memoria interna del autómata se pueden almacenar los resultados históricos de importantes variables relacionadas con el riego, como, por ejemplo: horas de riego, velocidad de la máquina, frecuencia de riego, cantidad de giros que efectúa la máquina, u otras que decida el cliente.

Para la transmisión de los datos se empleará un punto de acceso inalámbrico WiFi conectado al puerto Ethernet del autómata, empleando protocolo de comunicación TCP/IP. Luego, el control y supervisión de los parámetros de riego podrá realizarse desde una estación remota, utilizando dispositivos móviles inteligentes, tabletas o computadoras portátiles, buscando flexibilidad, de acuerdo con las posibilidades y necesidades del cliente. También se podrá operar desde la propia estación local, donde se tendrá acceso al autómata y a su configuración de hardware. Luego, la información manejada por él mismo, podrá ser mostrada en una página web que puede ser re-diseñada para cada máquina en específico o para un conjunto de ellas, brindando la capacidad de procesar los datos de riego para la toma de decisiones, de acuerdo con las características y el contexto de aplicación (tipo de cultivo, disponibilidad de los recursos hídricos, necesidades de mantenimiento, etc.).

\section{B. Visualización Web}

En función de la solución propuesta, se diseña la interfaz gráfica de usuario que se muestra en la Figura 4. La programación de sus elementos visuales y enlaces dinámicos con las variables del sistema se realiza medianteel software SoMachine v4.1 SP2.

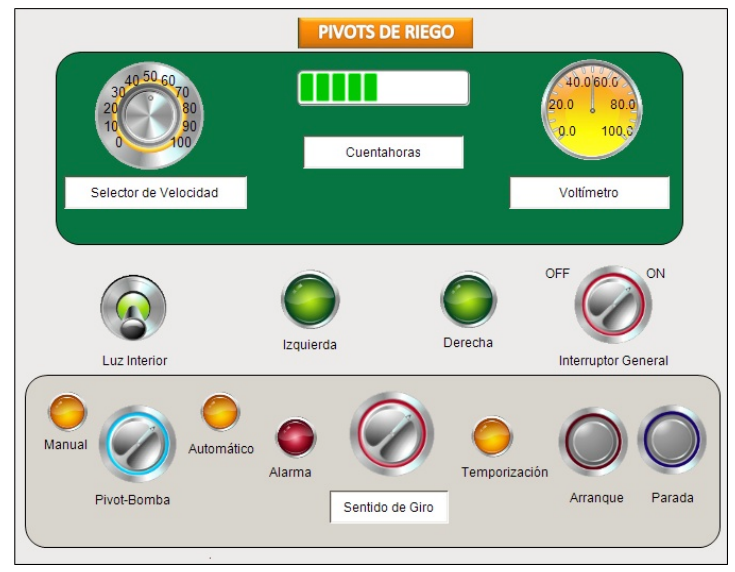

Figure 4. Proposed Web interface for supervision and control of central pivot irrigation machines / Interfaz web propuesta para la supervisión y control de las máquinas de pivote central

Entre las funcionalidades que brinda la interfaz se encuentran las siguientes:

- Selección del tiempo de trabajo de la máquina: ajustable según la norma de riego establecida.

- Registro de tiempo de funcionamiento: permite medir mediante un contador de horas el tiempo de operación de la máquina. 
- Selección del régimen de trabajo: se realiza gracias a botones selectores que permiten distinguir el modo manual-automático del funcionamiento de la máquina.

- Selección del sentido de giro de la máquina.

- Funcionalidades de operación: incluye botones de arranque y parada de la máquina y un interruptor para encender o apagar la luz interior y demás.

- Indicadores: permiten visualizar, a través de lámparas indicadoras, el estado de los parámetros de funcionamiento.

La funcionalidad del sistema supervisor, los reportes, los históricos, las alarmas y la información a mostrar, entre otros elementos, dependerán de las necesidades del usuario y de las posibilidades de comunicación que existan en cada entidad donde se implante el sistema, lo cual brinda flexibilidad a la solución propuesta.

\section{Conclusiones}

La propuesta de automatización y control inalámbrico para máquinas de riego de pivote central garantiza el seguimiento, por parte de directivos y operadores, del estado de funcionamiento de estas máquinas, lo que contribuye a lograr una mayor eficiencia en términos de ahorro del agua y de energía en los sistemas de irrigación agrícola en Cuba.

La solución de control remoto basada en tecnología inalámbrica permite la visualización y operación de las máquinas a través de páginas web, pudiendo acceder a la misma desde variados dispositivos, tales como celulares, tabletas, ordenadores etc.

Dependiendo de las facilidades y prestaciones de comunicación que pudieran existir en el lugar de aplicación de nuestra propuesta, se puede adaptar al empleo de otras tecnologías, por ejemplo: servicio GPRS (en telefonía móvil), trasmisión de la información en la banda de UHF y enlace mediante radio modem. Ello brinda un nivel de flexibilidad y aplicabilidad a la presente investigación.

\section{Agradecimientos}

Agradecemos el apoyo brindado por el Instituto de Investigaciones de la Caña de Azúcar (INICA) de Villa Clara (Cuba), por la ayuda desinteresada de los especialistas, directivos y personal técnico, en general, y por su gestión de facilitarlos los medios técnicos necesarios para el desarrollo de los experimentos efectuados en el Complejo Agro Industrial [CAI] Carlos Baliño del municipio de Santo Domingo. $\mathbf{S} T$
The features provided by the interface are:

- Selection of the machine working time: Adjustable according to the established irrigation norm.

- Operation time recording: It allows to measure the operation time of the machine by an hour counter.

- Selection of the work rate: It is done by selector buttons that allow distinguishing the manual-automatic mode of the machine operation.

- Selection of the machine rotation direction.

- Operation functionalities: It includes the machine start and stop buttons and a switch to turn on or off the interior light and others.

- Indicators: They allow to visualize the status of the operating parameters through indicator lamps.

The functionality of the supervisory system, the reports, the historical reports, the alarms and the information to be displayed, among other elements, are dependable of the user needs and the communication possibilities that exist in each sector where the system is implemented, which provides flexibility to the proposed solution.

\section{Conclusions}

The proposal of automation and wireless control for center pivot irrigation machines ensure the monitoring of the operating status of these machines by managers and operators. It contributes to achieving greater efficiency in terms of water and energy savings in agricultural irrigation systems in Cuba.

The remote control solution based on wireless technology allows the visualization and operation of the machines through web pages, being able to get an access from various devices, such as cell phones, tablets, computers, etc.

Depending on the communication possibilities that may exist in the application place of our proposal, it can be adapted to the use of other technologies, for example GPRS service (in mobile telephony), information transmission in the UHF band and link via a radio modem. The above provides a level of flexibility and applicability to the current research.

\section{Acknowledgments}

We are grateful for the support provided by the Sugar Cane Research Institute [INICA] (Villa Clara, Cuba), for the disinterested help of specialists, managers and technicals, and for providing us the necessary technical tools for the execution of the experiments carried out in the Agro-Industrial Complex Carlos Baliño of the municipality of Santo Domingo. ST 


\section{References / Referencias}

Alghazali, N., Alkhaddar, R., \& Hadi, H. (2013). The use of SCADA system in water resources management, management of Shatt Al-Hilla in Iraq as a case study. International Journal of Environmental Monitoring and Analysis, 1(5), $237-247$. doi:10.11648/j.ijema.20130105.19

Avello-Fernández, L., Izaguirre-Castellanos, E., Martínez-La Guardia, A. S. \& Hernández-Santana, L. (2017). Solución de control y supervisión remota para máquinas de riego de pivote central empleando tecnología inalámbrica [ponencia en XVII Simposio de Ingeniería Eléctrica, 2017, Universidad Central "Marta Abreu" de Las Villas.

Camargo, M. (2013). Sistema de control de riego automático mediante el monitoreo de humedad del suelo vía Internet [thesis]. Universidad Autónoma de Querétaro: México. Retrieved from: http://ri.uaq.mx/bitstream/123456789/1306/1/RI000591.pdf

Capraro, F., Tosetti, S., \& Vita-Serman, F. (2014). Supervisory control and data acquisition software for drip irrigation control in olive orchards: An experience in an arid region of Argentina. Acta Horticulturae, 1057, 423-429. doi: 10.17660/ActaHortic.2014.1057.53

Carranza, J. (2016). Soluciones de automatización para sistemas de regadío en caña de azúcar [thesis]. Universidad Central "Marta Abreu" de Las Villas: Santa Clara: Cuba

Chávez, J.L., Pierce, F.J., Elliott, T.V., \& Evans, R.G. (2010). A remote irrigation monitoring and control system for continuous move systems. Part A: Description and development. Precision Agriculture, 11(1), 1-10. doi:10.1007/s11119-009-9109-1

Clavelo, J.L.A. \& Seguí, J. P. (2012). Programación del riego de la caña de azúcar en la provincia de Villa Clara, Cuba. Revista Ciencias Técnicas Agropecuarias, 21(4), 61-66.

Dong, X., Vuran, M.C., \& Irmak, S. (2013). Autonomous precision agriculture through integration of wireless underground sensor networks with center pivot irrigation systems. Ad-Hoc Networks, 11(7), 1975-1987. doi:10.1016/j.adhoc.2012.06.012

González, O. (2016, May 24). La Cuba moderniza sistemas de riego. Granma [on-line]. Retrieved from: http://www.granma. cu/cuba/2016-05-24/la-cuba-moderniza-sistemas-de-riego-24-05-2016-23-05-09

Gurban, E. H. \& Andreescu, G.-D. (2011). SCADA element solutions using Ethernet and mobile phone network. In: Intelligent Systems and Informatics, 2011 IEEE 9th International Symposium on, (pp. 303-308). IEEE

Jiménez, E. (2011). Parámetros de explotación y uniformidad de riego en la máquina de pivote central OTECH-IRRIMEC. Revista Ingeniería Agrícola, 1(1), 7-12.

Joshi, G. S., Bhujbal, N. V., \& Kurkute, S. M. (2016). Agriculture at a Click Using PLC \& SCADA. International Journal of Emerging Trends in Science and Technology, 3(5), 3928-3932. doi:10.18535/ijetst/v3i05.13

Kranz, W.L., Evans, R.G., Lamm, F.R., O'Shaughnessy, S.A., Peters, T.R. (2010). A review of center pivot irrigation control and automation technologies. In: 5th National Decennial Irrigation Conference Proceedings. American Society of Agricultural and Biological Engineers. doi:10.13031/2013.35832)

Kumar, N.D., Pramod, S., Sravani, C.H. (2013). Intelligent irrigation system. International Journal of Agricultural Science and Research (IJASR), 3(30), 23-30.

Maheshwari, C.V. \& Sindha, D. (2014). Water irrigation system using controller. International Journal of Advanced Technology in Engineering and Science, 2(1), 240-249.

Navarro-Hellín, H., Martinez-del-Rincón, J., Domingo-Miguel, R., Soto-Valles, F. \& Torres-Sánchez, R. (2016). A decision support system for managing irrigation in agriculture. Computers and Electronics in Agriculture, 124, 121-131. doi:10.1016/j. compag.2016.04.003

Pasha, B.R.S. \& Yogesha, D.B. (2014). Microcontroller based automated irrigation system. The International Journal of Engineering and Science (IJES), 3(7), 6-9.

Pavithra, D.S. \& Srinath, M.S. (2014). GSM based automatic irrigation control system for efficient use of resources and crop planning by using an Android mobile. IOSR Journal of Mechanical and Civil Engineering (IOSR-JMCE), 11(4), 49-55.

Pérez, J. (2010). Diseño agronómico de un sistema de pivote central en la pequeña propiedad los arenales [thesis]. Universidad Autónoma Agraria "Antonio Navarro": Torreón, México.

Pfitscher, L.L., Bernardon, D.P., Kopp, L.M., Ferreira, A.A.B., Heckler, M.V.T., Thome, B.A., Montani, P.D.B., Fagundes, D.R. (2011). An automated irrigation system for rice cropping with remote supervision. In: 2011 International Conference on Power Engineering, Energy and Electrical Drives. IEEE. doi:10.1109/PowerEng.2011.6036452

Reductores CUÑAT. (2017). Cuñat agrocaja: pivots de riego. Retrieved from: www.reductorescunat.es/pivots.html

Reinke Irrigation. (2017). Reinke pivots. Retrieved from: skoneirrigation.com/reinke-pivots/

Rodríguez, M. \& López, T. (2014). Comportamiento de la zona radical activa del banano en un ferrasol bajo riego por goteo superficial y subsuperficial. Revista Ciencias Técnicas Agropecuarias, 23(3), 5-10.

Rodríguez, M. \& Puig, O. (2012). Comportamiento hidráulico de los sistemas de riego por goteo superficial y sub superficial. Revista Ciencias Técnicas Agropecuarias, 21(3), 23-28.

Santos, L., De Juan, J., Picornell, M., Tarjuelo, J. (2010). El riego y sus tecnologías. Albacete, España: Centro Regional de Estudios del Agua (CREA), Universidad de Castilla-La Mancha.

Schneider Electric. (2017). Automatización de máquinas y procesos. Rueil-Malmaison, France: Schneider Electric.

Smith, R.J., Baillie, J.N., McCarthy, A.C., Raine, S.R., \& Baillie, J.N. (2011). Review of precision irrigation technologies and their application [NCEA Publication 1003017/1]. Toowoomba, Australia: National Centre for Engineering in Agriculture University of Southern Queensland Toowoomba

Tarjuelo, J.M. (2005). El riego por aspersión y su tecnología. Madrid, España: Mundi-Prensa. 
United States Department of Agriculture [USDA] (1991). National engineering handbook. Washington, DC: USDA.

Valley Irrigation. (2017). Irrigation products leading the industry with advanced irrigation systems. Retrieved from: http://www. valleyirrigation.com/valley-irrigation/us/irrigation-products

Vázquez, R.J. \& Solano, O.J. (2013). Determinación del peligro por sequía agrícola. Revista Cubana de Meteorología, 19(2), 154-168. 


\section{CURRICULUM VITAE}

Lianet Avello Fernández Automation Engineer from the Universidad Central "Marta Abreu" de Las Villas [UCLV] (Cuba, 2016), professor at the Department of Automation and Computational Systems (Electrical Engineering Faculty, UCLV). Member of the Automation, Robotics and Perception Group [GARP]. She researches about automation of irrigation systems with applications in precision agriculture / Ingeniera en Automática de la Universidad Central "Marta Abreu" de las Villas [UCLV] (Cuba, 2016), profesora de su Departamento de Automática y Sistemas Computacionales (Facultad de Ingeniería Eléctrica) y miembro del Grupo de Automatización, Robótica y Percepción [GARP]. Investiga sobre automatización de sistemas de riego con aplicación en la agricultura de precisión.

Eduardo Izaguirre Castellanos Doctor in Sciences (2012) and Master in Automation (1997). Professor at the Automation Department (Faculty of Electrical Engineering, UCLV. His experience includes 9 years working for the industrial sector in Cuba and more than 25 years as a teacher in the UCLV. He won several provincial CITMA awards and one national ACC. As member of the Automation, Robotics and Perception Research Group [GARP], he researches in modeling, simulation and control of mechatronic systems and automation with application in precision agriculture and irrigation systems / Doctor en Ciencias (2012) y Máster en Automática (1997). Profesor titular del Departamento de Automática de la Facultad de Ingeniería Eléctrica de la UCLV. Cuenta con nueve años de experiencia laboral en el sector industrial en Cuba y más de veinticinco como docente en la UCLV. Ha obtenido varios premios CITMA provinciales y uno ACC nacional. Como miembro del Grupo de Investigaciones de Automática, Robótica y Percepción [GARP], investiga sobre modelado, simulación y control de sistemas mecatrónicos y automatización con aplicaciones en agricultura de precisión y sistemas de riego.

Manuel Luciano Vidal Díaz Agronomy Engineer and Doctor in Technical Sciences from the UCLV (Cuba). $\mathrm{He}$ carries out his scientific work in irrigation, thematic area in which he has extensive experience. He worked as Director of the Sugar Cane Research Territorial Station [ETICA] of Villa Clara (Cuba) and currently works at the National Institute of Sugar Cane (INICA), as head of department and researcher in issues related to precision agriculture applied to cane cultivation / Ingeniero Agrónomo y Doctor en Ciencias Técnicas de la UCLV (Cuba). Realiza su trabajo científico en la especialidad de riego, área temática en la que cuenta con una amplia experiencia. Trabajó como Director de la Estación Territorial de Investigaciones de la Caña de Azúcar [ETICA] de Villa Clara (Cuba) y actualmente labora en el Instituto Nacional de la Caña de Azúcar (INICA), como jefe de departamento y en investigaciones relacionadas con la agricultura de precisión en el cultivo de la caña.

Alain Sebastián Martínez Laguardia Engineer in Automation and Master in Telematics from the UCLV (Cuba, 2001 and 2005, respectively), with a Ph.D., in Engineering (Université libre de Bruxelles, Belgium and the UCLV, 2015). Since 2001 he is a member of the Automation and Computer Systems Department of the UCLV, where he is currently a full professor and head of the department. Founder of the Automation, Robotics and Perception Group, since 2003 he has been researching about the design of embedded systems and the development and application of autonomous vehicles / Ingeniero en Automática y Máster en Telemática de la UCLV (Cuba, 2001 y 2005, respectivamente), con un doctorado conjunto en Ingeniería entre la Université libre de Bruxelles (Bélgica) y la UCLV (2015). Desde 2001 es miembro del Departamento de Automática y Sistemas Computacionales de la UCLV, donde actualmente es profesor titular y jefe del departamento. Fundador del Grupo de Automatización, Robótica y Percepción, desde 2003 investiga en el diseño de sistemas empotrados y el desarrollo y aplicación de vehículos autónomos.

Luis Hernández Santana Engineer in Control-Automation and Doctor in Technical Sciences from the UCLV (Cuba). At the UCLV he is a professor of the Department of Automation and Computer Systems and the Scientific Responsible for the Automation Robotics and Perception Group [GARP]. He conducts research about guidance and control of autonomous vehicles and in topics of precision agriculture, including: automatic irrigation systems, automation of agricultural machinery and use of unmanned aerial vehicles in crop monitoring. Also, he leads research projects related to precision agriculture / Ingeniero en Control-Automático y Doctor en Ciencias Técnicas de la UCLV (Cuba), institución donde es profesor titular del Departamento de Automática y Sistemas Computacionales y Responsable Científico del Grupo de Automatización Robótica y Percepción [GARP]. Investiga sobre guiado y control de vehículos autónomos y en temas de agricultura de precisión que incluye: los sistemas automáticos de riego, la automatización de la maquinaria agrícola y el uso de vehículos aéreos no tripulados en para monitoreo de cultivos. Dirige proyectos de investigación relacionados con la agricultura de precisión. 